\title{
DIGITALCOMMONS
}

@WAYNESTATE-

Wayne State University

$12-15-2020$

\section{Genomic Heterogeneity of the Naga and Kuki Tribal Populations of Manipur, North-East India}

\author{
Gangaina Kameih \\ University of Delhi \\ Somorjit Singh Ningombam \\ All India Institute of Medical Sciences, New Delhi, India \\ Gautam Kumar Kshatriya \\ University of Delhi
}

Follow this and additional works at: https://digitalcommons.wayne.edu/humbiol_preprints

\section{Recommended Citation}

Kameih, Gangaina; Singh Ningombam, Somorjit; and Kumar Kshatriya, Gautam, "Genomic Heterogeneity of the Naga and Kuki Tribal Populations of Manipur, North-East India" (2020). Human Biology Open Access Pre-Prints. 180.

https://digitalcommons.wayne.edu/humbiol_preprints/180

This Article is brought to you for free and open access by the WSU Press at DigitalCommons@WayneState. It has been accepted for inclusion in Human Biology Open Access Pre-Prints by an authorized administrator of DigitalCommons@WayneState. 
Genomic Heterogeneity of the Naga and Kuki Tribal Populations of Manipur, North-East India

Gangaina Kameih, ${ }^{1 *}$ Somorjit Singh Ningombam, ${ }^{2}$ and Gautam Kumar Kshatriya ${ }^{3}$

${ }^{1}$ Biochemical and Molecular Anthropology Laboratory, Department of Anthropology, University of Delhi, Delhi, India.

${ }^{2}$ Laboratory Oncology, Dr. B.R.A. Institute Rotary Cancer Hospital, All India Institute of Medical Sciences, New Delhi, India.

${ }^{3}$ (Emeritus) Department of Anthropology, University of Delhi, Delhi, India.

*Correspondence to: Gangaina Kameih, Biochemical and Molecular Anthropology Laboratory, Department of Anthropology, University of Delhi, Delhi-110007, India. E-mail: gangaina.k@gmail.com.

Short Title: Genomic Heterogeneity of the Naga and Kuki Tribal Populations

KEY WORDS: NAGA, KUKI, INPUI, TRIBAL POPULATIONS, MANIPUR AND GENETIC HETEROGENEITY.

\begin{abstract}
Manipur is one of the North-Eastern states of India and it lies on the ancient silk route and serves as a meeting point between the Southeast Asia and South Asia. The origin and migration histories of Naga and Kuki tribal populations have not been clearly understood. Moreover, Kukis
\end{abstract}


have been traced to two different ancestries, which have created confusion among the people. The present study examined genomic affinities and differentiation of the Naga and Kuki tribal populations of Manipur, Northeast India. Twenty autosomal markers (Eight Alu InDels, and twelve Restriction Fragment Length Polymorphisms) were analysed. Findings showed genetic differences between Naga and Kuki tribal populations with respect to the allele distribution pattern which was substantiated by genetic differentiation (Gst 5.2\%) and molecular variance (AMOVA) where the highest percentage of among group variances was observed between Naga and Kuki tribal groups (7.09\%). However, genetic similarity with respect to allele distribution pattern in most of the loci were seen among their respective groups (Rongmei and Inpui; Thadou and Vaiphei). Rongmei and Inpui tribal populations (Naga group) belong to Naga-Bodo linguistic group and Thadou and Vaipei (Kuki group) belong to Northern Kuki-Chin linguistic group suggesting that genetic similarities may not be independent of linguistic affinities. Despite differential genetic affinities, both Naga and Kuki tribal populations in Manipur show proximity with Southeast Asian populations and Northeast Indian populations than with other Indian populations and global populations taken for comparison.

Pre-print version. Visit http://digitalcommons.wayne.edu/humbiol/ after publication to acquire the final version. 
The contemporary Indian tribal populations constitute $8.6 \%$ of the total population. About $90 \%$ of them live in rural areas and only 10\% live in urban areas. In general, Scheduled Tribes (STs) inhabit two distinct geographical areas; Central India and North-Eastern India (Chakma et al. 2017). Manipur is a tiny state situated in the easternmost part of North Eastern region of India. The state is bounded on the south and east of Burma (Myanmar), on the north by Nagaland, on the west by Assam and on the southwest by Mizoram. It lies on the ancient silk route and serves as a meeting point between the Southeast Asia and South Asia (Meitei et al. 2010). Manipur's great diversity comprises of Meitei, Naga, Kuki, Meitei-Pangal and immigrant populations. Naga and Kuki are the tribal groups of Manipur. There are 34 recognized tribes spread over 16 districts in Manipur (Ministry of tribal affairs, Government of India).

Some of the earlier studies classified Naga as nearly akin to the Kuki. However, there are few distinctive features which set apart the Naga and Kuki groups (Rizvi \& Roy 2006). The differences are summarised here. The village government of Naga is distinctly democratic wherein the chieftainship does not necessarily inherit by a son from his father. Among Kuki, the chiefs invariably inherit the position by virtue of their birth and thus an autocratic form of village government prevails. These chiefs take the initiative in all matters concerning the administration of their clansmen by whom they are respected and feared. There is marked differences between the Naga and Kuki in methods of cultivation of crops. Naga developed terrace cultivation whereas Kuki practice Jhuming. The Nagas males did not keep their hair long in the past while the Kuki males kept their hair in knot either at the back of the neck or at the occiput (e.g. Paite, Thadou, Hmar tribes). The settlement pattern of these two groups also markedly differs. The Naga people construct their houses on a flattened surface, and the floor (made of soil) is directly touching the ground while Kuki people construct their houses on a sloping surface of the earth and the floor is 
not made of soil but bamboo matting is used. The houses of the chief and affluent Naga are conspicuous by bearing a horn like structure on the ridge of the steep roofs while the houses of the chiefs of Kuki people are normally larger in size having a large verandah. In sharp contrast to Naga tribes, the languages of Kuki tribes are close to each other with minor differences (Haokip 2011) and they are found everywhere in Manipur except in the territory occupied by the Mao confederacy (Hodson 1911).

The Rongmei, Inpui, Thadou and Vaiphei are recognized tribal groups of Manipur. The two population groups (Rongmei and Inpui) are falling under the category of Naga tribes and the other two population groups (Thadou and Vaiphei) are falling under the category of Kuki tribes. The total population of Rongmei is 90,372 (Tohring 2010) and Inpui is 11,000 (Devi 2013). According to the 2001 census of India, the total population of Thadou and Vaiphei are 1,82,594 and 38,267 respectively. Linguistically, all the four ethnic groups are the speakers of TibetoBurman groups however, based on their genetic relationships, the languages of Manipur have broadly divided into two groups (Naga and Kuki-Chin) and further into several subgroups (Haokip 2011). Rongmei and Inpui belong to Naga-Bodo subgroup (Grierson 1903) on the other hand Thadou and Vaiphei belong to Northern Kuki-Chin subgroup (Grierson 1904; Thurgood and Lapolla 2003).

The origin and migration history of the populations of Manipur are not clearly understood. Archaeological findings have revealed that Manipur was inhabited by prehistoric man since Stone Age (Singh 1997). Manipur's prehistoric cultural affinity with the Chinese Neolithic culture of the second millennium B.C. has been exposed at the Napachik site (Singh 1983a). On the basis of stone tool evidence, it was deduced (Singh 1983b) that wave of people from the regions of South China migrated to Manipur. Jacobs (1990) also suggested that the 
migrations must have occurred through China, Tibet and Burma during different periods of time. The tribes of Naga are believed to have migrated from Southwest China (Gangmei 2017; Kamei 2014; Kamei 2015; Kameih et al. 2018) in the western hills of Manipur most probably in the second half of the $13^{\text {th }}$ century A.D. On the other hand, the arrivals of Kuki in Manipur have probably two different sources of origins. One is an Israelite origin, i.e. European ancestry (Mukherjee 1998; Haokip 2010) and the other one is Burmese origin i.e. Southeast Asian ancestry (Rizvi \& Roy 2006; Saraswathy et al. 2009a). They are known to be the late migrants to Manipur who entered sometimes in late $18^{\text {th }} /$ early $19^{\text {th }}$ century A.D.

Few studies have been carried out on the populations of Manipur (Saraswathy et al. 2009a; Saraswathy et al. 2009b; Meitei et al. 2010; Kameih et al. 2018; Kshatriya et al. 2019) however, not on same genetic markers, most of them on different populations with different objectives. Rongmei and Inpui were earlier grouped and identified as Kabui Naga prior 2011 census therefore earlier studies (Saraswathy et al. 2009b; Meitei et al. 2010) had done sampling based on blanket term 'Kabui' without specifying names of Rongmei and Inpui. Keeping this in view, we report an analysis of 20 autosomal markers including eight insertion-deletion polymorphisms and twelve restriction site polymorphisms (both linked and unlinked) in four tribal populations of Manipur (two populations each from Naga and Kuki tribes), Northeast India. The objectives of the present study are i) to assess the extent of genetic heterogeneity among Rongmei, Inpui, Thadou and Vaiphei tribes of Manipur, and ii) to examine their probable parental affinities using the available datasets from the populations across the world.

\section{Materials and Methods}

\section{Study Subjects}

Pre-print version. Visit http://digitalcommons.wayne.edu/humbiol/ after publication to acquire the final version. 
The present study was conducted among four tribal populations belonging to Naga (Rongmei, Inpui) and Kuki (Thadou and Vaiphei) tribes of Manipur. The four study population groups were selected from Tamenglong, Noney, Imphal West, Senapati, Kangpokpi, Chandel and Churchandpur districts, precisely because of their predominant distribution in these districts (Fig. 1). Intravenous blood samples $(5 \mathrm{ml})$ were collected from 310 unrelated (beyond great grandparents) individuals (110 Rongmei, 100 Inpui, 67 Thadou and 33 Vaiphei) of either sex in the age group 18-60 years, from the four population groups. Simple random sampling technique was used in the selection of subjects. The blood was taken by a trained medical practitioner after taking informed written consent from the subjects. The study was approved by the Departmental Ethics Committee, Department of Anthropology, University of Delhi, New Delhi.

\section{Laboratory Analysis}

After the blood sample was collected, DNA extraction was done using the salting-out method (Miller et al. 1988). The concerned genomic regions were first amplified using a standard Polymerase Chain Reaction (PCR) to screen the samples for 20 autosomal loci and then digested with appropriate restriction enzymes in the case of Restriction Fragment Length Polymorphisms (RFLPs). This was followed by imaging results through electrophoresis in agar gels stained with ethidium bromide and visualized under UV rays. For the present study, eight Alu InsertionDeletion polymorphisms (AluInDels), namely ACE, APO, D1, FXIIIB, PLAT, PV92, mt-NUC and CD4; six unlinked RFLPs, namely ESR (Pvu II), NAT (Kpn I), PSCR (Taq I), T2 (Msp I), LPL ( $P v u$ II) and HOXB4 (Msp I); three linked RFLP sites in DRD2 gene, namely Taq I 'A', Taq I 'B' and Taq I 'D'; and three linked RFLP sites in $\beta$-globin gene, namely Hb7 (HincII), Hb8 (HincII) and Hb9 (Hinfl) were analysed. The primers and protocols have been described 
elsewhere (Jorde et al. 1995; Stoneking et al. 1997; Kidd et al. 1998; Majumder et al. 1999a; Lee et al. 2002; ALFRED database).

\section{Statistical Analysis}

Allele frequencies for each selected site were obtained using the software POPGENE version 1.31 (Yeh \& Yang 1999). Hardy-Weinberg equilibrium was calculated using the test for chisquare goodness of fit. Bonferroni’s correction for multiple comparisons was also applied. Average heterozygosities were calculated using the software DISPAN (Ota 1993). The haplotype frequencies (for linked loci) and analysis of molecular variance (AMOVA) were computed using the software ARLEQUIN version 3.5 (Excoffier \& Lischer 2010). To assess genetic relationships among the populations, multidimensional scaling (MDS) analyses were performed using the software SPSS version 17.0.

\section{Results}

The allele frequencies for the 20 loci in the four study populations are presented in Table1 along with the number of chromosomes examined. All the loci are found to be polymorphic in all the populations. When applying the chi-square goodness of fit test to determine whether the phenotype and genotype frequencies depart from Hardy-Weinberg proportions and using Bonferroni's correction, it is observed that the phenotype (genotype) frequencies for most of the loci are in reasonable agreement with their respective Hardy-Weinberg expectations and do not show significant departure from expected frequencies. Taq I D locus exhibits maximum variation across the populations ranging from $25.9 \%$ among Vaiphei to $80.9 \%$ among Inpui. CD4 locus 
shows least variation across the populations ranging from $89.1 \%$ among Vaiphei to $98.2 \%$ among Inpui.

The heterozygosity at each locus and the average heterozygosity over all the loci for the study populations are presented in Table 2 . The heterozygosity value of all the loci is found to be moderate in all groups. The overall average heterozygosity among the four study populations vary from 0.372 in Vaiphei to 0.394 in Rongmei.

\section{Genomic Diversity Analysis}

Table 3 presents the estimate of genetic diversity for each locus and for all the loci together among the four study populations of Manipur. The four study groups seem to differ most at TaqI 'D'locus (GST=27.9\%) and least at PV92 locus $\left(\mathrm{G}_{\mathrm{ST}}=1.1 \%\right)$. When all the markers are considered jointly, the Gst value was $5.2 \%$, which may be attributable to variation between populations. The total genomic diversity among the subpopulations revealed overall moderate levels of heterozygosity, where $\mathrm{H}_{\mathrm{T}}$ ranges from a minimum of 0.114 at CD4 locus to a maximum of 0.498 at FXIIIB locus

\section{Haplotype Frequencies}

Data pertaining to DRD2 and $\beta$-globin haplotype frequencies among the studied populations of Manipur are presented in Table 4 and 5 respectively.

With respect to haplotype analysis at DRD2 system, five out of the total eight possible haplotypes were shared by all the studied populations. Only Rongmei showed all the eight possible haplotypes which indicate the maximum diversity. Thadou, Vaiphei and Inpui showed 
seven of the eight possible haplotypes. Ancestral haplotype B2D2A1 was found in all the four study groups and its frequency ranges from $8.1 \%$ in Vaiphei to $15.6 \%$ in Rongmei.

With respect to $\beta$-globin system, +-- haplotype is observed to be the most prevalent in all the four populations ranging from $31.5 \%$ in Inpui to $60.1 \%$ in Vaiphei. It is observed that five out of the total eight possible haplotypes were shared by all the studied populations. Thadou and Inpui showed all the eight possible haplotypes. Rongmei showed seven of the eight possible haplotypes and Vaiphei showed six of the eight possible haplotypes.

The extent of genetic differentiation as is shown by analysis of molecular variance (AMOVA) among the populations based on language and ethnicity indicate that among individual variation or intrapopulation variation is highest among all the categories (Table 6). The highest percentage of among group variance is seen between Naga and Kuki groups (7.09\%) followed by variance between four linguistic groups of India (3.23\%), between castes and tribal groups $(1.92 \%)$ and between the presently studied groups and Southeast Asia (1.18\%). With regard to variation of Kuki tribes and Naga tribes in the present populations, between-group variation is higher $(7.09 \%)$ as compared with interpopulation variation among the groups $(0.31 \%)$. It means that the greater genetic difference is observed between Naga and Kuki tribes, suggesting their different gene pool.

\section{Discussion}

Analysis of allele frequency distribution at 20 autosomal DNA loci among the presently studied four populations revealed that differences in the frequency pattern were observed at some loci between Naga (Rongmei and Inpui) and Kuki (Thadou and Vaiphei) groups (Fig.2). However, Rongmei and Inpui (Naga tribes) which belongs to Naga-Bodo linguistic group have a similar 
allele distribution pattern. It was also observed that Thadou and Vaiphei (Kuki tribes) who are the speakers of Northern Kuki-Chin linguistic group showed a similar allele frequency distribution. The genetic distances matrices also revealed that the least value between Rongmei and Inpui (0.002) followed by Thadou and Vaiphei (0.005). It is therefore conceivable that genetic similarities may not be independent of linguistic affinities; similar view was given by Haokip (2011), who opined that the linguistic subgroups of Manipur were based on genetic relationship.

When allele frequencies among the presently studied four study populations at five polymorphic Alu loci were compared with other populations of Manipur, Indian populations and the global populations, they showed close affinities with Southeast Asian populations suggesting their genetic proximity with these populations (Fig. 3).

In India, the frequency of ancestral allele B2 at the TaqIB site varies from as low as $36.7 \%$ in the Onge tribe (Bhaskar et al. 2008) to as high as $91 \%$ among the Toda tribe (Vishwanathan et al. 2003), with median values estimated to be $67 \%$ (Chakrabarti et al. 2002; Vishwanathan et al. 2003; Bhaskar et al. 2008; Prabhakaran et al. 2008; Saraswathy et al. 2009a, 2010; Kshatriya et al. 2010; Sinha et al. 2015). The median B2 allele value of the presently studied populations is $56 \%$, which is closer to the value of 59\% computed from Chinese populations (Kidd et al. 1998). The distribution of D2 allele frequencies ranges from 13.9\% in Paite (Saraswathy et al. 2009a) to 98.3\% in Mizo (Chakrabarti et al. 2002), with median values estimated to be 58\% (Chakrabarti et al. 2002; Vishwanathan et al. 2003; Bhaskar et al. 2008; Prabhakaran et al. 2008; Saraswathy et al. 2009a, 2010; Kshatriya et al. 2010; Sinha et al. 2015). Further, the median D2 allele value of the two presently studied Naga (Rongmei and Inpui) populations are 79\%, which is closer to the value 93\% computed from Chinese populations (Kidd et al. 1998) rather than with the Indian populations. The ancestral A1 allele is highly variable in India (Chakrabarti et al. 2002; 
Vishwanathan et al. 2003; Bhaskar et al. 2008; Prabhakaran et al. 2008; Saraswathy et al. 2009a, 2010; Kshatriya et al. 2010; Sinha et al. 2015) and with A1 varying between $38 \%$ and $49 \%$ among the two presently studied Naga (Rongmei and Inpui) populations, they are akin to Chinese population groups. The overall allele frequencies among the four presently studied groups revealed that the two presently studied Naga (Rongmei and Inpui) populations show close resemblances to Zeme and Liangmai, the cognate groups of Zeliangrong (Kameih et al. 2018) and also to the Chinese populations. In contrast to the two presently studied Naga (Rongmei and Inpui) population groups, the other two presently studied Kuki (Thadou and Vaiphei) population groups is comparable to Paite and Kom (Saraswathy et al. 2009a) which have also belonged to Kuki population groups, indicating their closeness of being common ancestry.

The average heterozygosity in the present study using the 20 markers varies from 0.372 in Vaiphei to 0.394 in Rongmei. It is known that the average heterozygosity levels vary with the kind of markers analysed. Therefore, when compared with studies carried out on a similar set of 18 markers, average heterozygosity levels of the four study populations are lower than the reported heterozygosity values of other Indian populations, reaching the maximum theoretical value of 0.5 (Majumder et al. 1999a; Mukherjee et al. 2000; Veeraju et al. 2001; Vishwanathan et al. 2004; Saraswathy et al. 2008; Kshatriya et al. 2011) but it is comparable to the reported values from other populations of Manipur (Saraswathy et al. 2009a).

The gene differentiation value (GST $5.2 \%$ ) on the basis of 20 autosomal loci observed in the presently studied four populations is found to be greater than that observed in some studies (Mukherjee et al. 2000; Veeraju et al. 2001; Saraswathy et al. 2008; Kshatriya et al. 2011) but smaller than observations from other studies (Vishwanathan et al. 2004; Saraswathy et al. 2009a). Vishwanathan et al. (2004) carried out a study on tribal groups of Tamil Nadu and found Gst to be 
$6.70 \%$ on the basis of 24 autosomal DNA markers. Meitei et al. (2010) conducted a study among population groups of Manipur using 7 alu InDel markers and found higher Gst value among tribal populations (7.4\%) than non-tribal populations (2.2\%) and it reveals that the diversity within the tribal groups is higher when compared with non-tribal. The high degree of genetic differentiation $(5.2 \%)$ in these populations could be suggestive of their different origin of these populations maintaining its own gene pool without the possibility of gene flow, following strict endogamous nature which is further supported by AMOVA analysis which indicates that the highest percentage of among group variance is seen between Naga and Kuki groups (7.09\%) as compared to interpopulation variation among the groups $(0.31 \%)$. When the four presently studied populations and the earlier studied populations from Manipur (Saraswathy et al. 2009a; Saraswathy et al. 2009b; Meitei et al. 2010; Kameih et al. 2018; Kshatriya et al. 2019) are considered jointly on the basis of five markers, the Gst value was $4.6 \%$, which may be attributable to variation among the populations of Manipur.

Five out of the total eight possible haplotypes were shared by all the presently studied populations. Only Rongmei showed all the eight possible haplotypes which indicate that they are more heterogeneous suggesting that they might have undergone admixture with Inpui because the Inpui villages on the foothill of the western Imphal valley have largely adopted the Rongmei culture and dialect as the result of the acculturation (Khumba 2001). Ancestral haplotype B2D2A1 was found in all the four study groups and its frequency ranges between $8.1 \%$ in Vaiphei and $15.6 \%$ in Rongmei. The frequency of ancestral haplotype B2D2A1 in the four tribal populations of Manipur is not as high as that observed in African populations (Kidd et al. 1998) and some of the south Indian tribal populations (Saraswathy et al. 2008, 2009c). Study from Manipur (Saraswathy et al. 2009a) reported the frequency of ancestral haplotype vary from as little as 1.2\% (Paite) to as 
high as $22.8 \%$ (Meitei) and conclude that this could be attributed to the different origins of the populations included in the study.

With respect to $\beta$-globin haplotypes, the haplotype '- ++'which has been reported to be associated with $\mathrm{HbS}$ in India (Majumder et al. 1999b) is found in frequencies range from $0 \%$ in Rongmei to $3.89 \%$ in Inpui. These haplotype frequencies are comparable with the findings that observed from other study from Manipur (Saraswathy et al. 2009a) but lower than the value observed from some of the west Indian populations and South Indian populations (Kshatriya et al. 2011; Saraswathy et al. 2008). The distribution pattern of another haplotype '+ - -' which has been reported to be linked with $\mathrm{HbA}$ in India (Majumder et al. 1999b), is found to be vary from $31.5 \%$ in Inpui to $60.1 \%$ in Vaiphei. These haplotype frequencies are comparable with the findings that observed from other study from Manipur (Saraswathy et al. 2009a) but greater than the value observed from South Indian populations (Saraswathy et al. 2008).

Multidimensional scaling (MDS) plot analyses reveal that Kuki tribal populations were found to cluster together with the Southeast Asian populations, whereas the European populations were distinctly far from Kuki tribal groups and Southeast Asian populations (Fig. 4). This clearly is indicative of the Kukis affinities with the Southeast Asians. Therefore, this contradicts the Israelite origin theory given by Khuplam Milui Lenthang (Haokip 2010) which may be attributed to the influence of the protestant missionaries who came to Manipur and Mizoram and were inclined to afford more respect to the Old Testament. Ningombam et al. 2018 also pointed out that Israelite origin theory (i.e. European ancestry theory) may not be valid because of their close affiliation with Southeast Asia people, both in terms of morphology and language. Saraswathy et al. (2009a) has also reported that the populations of Manipur share their ancestry with the Southeast Asian populations. Furthermore, MDS plot analysis of the global populations presented in Fig. 5 also 
reveals that both Naga and Kuki tribal populations (Rongmei, Inpui, Thadou and Vaiphei) along with the other populations of Manipur are clustering together with Southeast Asian populations rather than with other Indian populations or European suggesting their genomic proximity to the populations of Southeast Asia.

The present study thus highlights the genetic affinities and differentiation of the two major tribes (Naga and Kuki) of Manipur. Genetic differences are observed between Naga and Kuki tribal populations with respect to the allele distribution pattern which was substantiated by genetic differentiation (GST) and molecular variance analyses. It is therefore conceivable that Kuki and Naga tribes certainly have their different migration history. Genetic distances matrices indicate that the least value was observed between Rongmei and Inpui followed by Thadou and Vaiphei. Further on comparing genes and language, Rongmei and Inpui tribal populations (Naga group) who belong to Naga-Bodo linguistic group have similar allele distribution pattern in most

of the loci. It was also observed Thadou and Vaiphei (Kuki) who are the speakers of Northern Kuki-Chin linguistic group showed similar allele frequency distribution suggesting that genetic similarities may not be independent of linguistic affinities. Finally, although Naga and the Kuki tribes are genetically, culturally and linguistically diverse to some extent, yet both the groups show genetically closer to the Southeast Asian populations rather than the Europeans.

\section{Acknowledgments}

The help rendered by Dr. Tabitha Panmei and the people of Rongmei, Inpui, Thadou and Vaiphei during the collection of blood samples is highly appreciated. We express our gratitude to Dr. Sanju Kumar, Department of Biotechnology, Manipur University, for his help by providing laboratory facilities for DNA extraction. We also acknowledge the University Grant Commission 
for providing the financial assistance through JRF vide letter no. 662/(NET-JUNE 2014) to Gangaina Kameih.

Received 1 June 2020; accepted for publication 2 September 2020. 


\section{Literature Cited}

Alfred Database. 1999. (Allele Frequency Database): A resource of gene frequency data on human populations supported by the U.S. National Science Foundation. http://alfred.med.yale.edu/alfred/index.asp (accessed 7 November 2017).

Bhaskar, L. V. K. S., K. Thangaraj, C. J. Mulligan et al. 2008. Allelic variation and haplotype structure of the dopamine receptor gene DRD2 in nine Indian populations. Genet. Test. 12:153-160.

Chakma, T., A. Kavishwar, R. K. Sharma et al. 2017. High prevalence of hypertension and its selected risk factors among adult tribal population in central India. Pathog. Glob. Health 111:343-350.

Chakrabarti, C. S., M. Roy, N. K. Sengupta et al. 2002. Genetic relationships among some tribal groups inhabiting the north-eastern, eastern and sub-Himalayan regions of India. Ann. Hum. Genet. 66:361-368.

Devi, W. P. 2013. Inpui adverbs. Int. J. Engl. Educ. 2:315-323.

Excoffier, L., and H. E. Lischer. 2010. Arlequin suite ver 3.5: A new series of programs to perform population genetics analyses under Linux and Windows. Mol. Ecol. Resour. 10:564-567.

Gangmei, N. 2017. The history of the Rongmei migration. Rongmei Encyclopedia, 23 July. https://rongmeiencyclopedia.wordpress.com/2017/07/23/the-history-of-the-rongmeimigration/ (accessed 16 April 2018).

Grierson, G. A. 1903. Linguistic Survey of India: Tibeto-Burman Family. Specimens of the Bodo, Nāgā, and Kachin Groups. Vol. III, part II. Delhi, IND: Low Price Publications, reprint 2005. 
Grierson, G. A. 1904. Linguistic Survey of India: Tibeto-Burman Family. Specimens of the KukiChin and Burma Groups. Vol. III, part III. Delhi, IND: Low Price Publications, reprint 2005.

Haokip, L. 2010. Historical chronology of Kuki people from B.C. 700-1919 A.D. Kuki International Forum, 16 December. http://kukiforum.com/2010/12/historical-chronologyof-kuki-people-from-bc-700-1919-ad/.

Haokip, P. 2011. The languages of Manipur: A case study of the Kuki-Chin languages. Linguist. Tibeto-Burman Area 34:85-118.

Hodson, T. C. 1911. The Naga Tribes of Manipur. Delhi, IND: Low Price Publication, reprint 2007.

Jacobs, J. 1990. The Nagas: Hill Peoples of Northeast India. London: Thames and Hudson.

Jorde, L. B., M. J. Bamshad, W. S. Watkins et al. 1995. Origins and affinities of modern humans: A comparison of mitochondrial and nuclear genetic data. Am. J. Hum. Genet. 57:523538.

Kamei, B. 2015. Origin, migration and settlement: The Zeliangrong of NE, Part 4. The Sangai Express, 26 April. http://epao.net/epSubPageExtractor.asp?src=manipur.Ethnic_Races_Manipur.Origin_migration_ and_settlement_The_Zeliangrong_of_NE_Part_4_By_Budha_Kamei.

Kamei, S. 2014. Paradoxical nature of Zeliangrong identity and the dynamics of recognition for constitutional benefits. J. Tribal Intellect. Collect. India 2:48-75.

Kameih, G., T. Panmei, and G. K. Kshatriya. 2018. Allelic variation and haplotype diversity of the dopamine receptor gene DRD2 among the four sub-populations of Zeliangrong Naga of Manipur. J. Indian Anthropol. Soc. 53:249-259. 
Khumba, K. A. 2001. The Inpui Nagas: Traditional culture and Christianity. The Inpui Naga Tribe, https://sites.google.com/site/inpuinaga/ (accessed 23 November 2017).

Kidd, K. K., B. Morar, C. M. Castiglione et al. 1998. A global survey of haplotype frequencies and linkage disequilibrium at the DRD2 locus. Hum. Genet. 103:211-227.

Kshatriya, G. K., A. Aggarwal, P. Khurana et al. 2010. Genomic and linguistic affinities: A study of allelic and haplotype diversity at DRD2 locus among the tribes of Gujarat, western India. Genet. Test. Mol. Biomarkers 14:215-223.

Kshatriya, G. K., A. Aggarwal, P. Khurana et al. 2011. Genomic congruence of Indo-European speaking tribes of western India with Dravidian-speaking populations of southern India: A study of 20 autosomal DNA markers. Ann. Hum. Biol. 38:583-591.

Kshatriya, G. K., T. Panmei, and G. Kameih. 2019. Alu insertion-deletion polymorphisms in the Tibeto-Burman speaking tribal groups of Manipur, North-East India. Gene Rep. 15:100372.

Lee, Y. J., S. S. Park, J. Y. Kim et al. 2002. RFLP haplotypes of beta-globin gene complex of beta-thalassemic chromosomes in Koreans. J. Korean Med. Sci. 17:475-478.

Majumder, P. P., B. Roy, R. S. Balgir et al. 1999b. Polymorphisms in the $\beta$-globin gene cluster in some ethnic populations of India and their implications on disease. In Molecular Intervention in Disease, S. Gupta and O. P. Sood, eds. New Delhi, IND: Ranbaxy Science Foundation, 75-83.

Majumder, P. P., B. Roy, S. Banerjee et al. 1999a. Human-specific insertion/deletion polymorphisms in India populations and their possible evolutionary implications. Eur. $J$. Hum. Genet. 7:435-446. 
Meitei, K. S., S. Y. Meitei, M. Asghar et al. 2010. A genomic insight into the peopling of Manipur, India. Genet. Test. Mol. Biomarkers 14:765-773.

Miller, S. A., D. D. Dykes, and H. F. Polysky. 1988. A simple salting out procedure for extracting DNA from human nucleated cells. Nucleic Acids Res. 16:1,215.

Ministry of Tribal Affairs, Government of India. N.D. State/Union Territory-wise list of scheduled tribes in India. https://tribal.nic.in/ST/LatestListofScheduledtribes.pdf (accessed 23 July 2020).

Mukherjee, S. K. 1998. Jewish movement in the hills of Manipur and Mizoram. In Social Movements in North-East India, M. N. Karna, ed. New Delhi, IND: Indus Publishing Company/NEICSSR, 189-198.

Mukherjee, N., M. Mitra, M. Chakraborty et al. 2000. Congruence of genomic and ethnolinguistic affinities among five tribal populations of Madhya Pradesh (India). $J$. Genet. 79:41-46.

Ningombam, S. S., V. Chhungi, M. K. Newmei et al. 2018. Differential distribution and association of FTO rs9939609 gene polymorphism with obesity: A cross-sectional study among two tribal populations of India with East-Asian ancestry. Gene 647:198-204.

Office of the Registrar General. 2001. Manipur Data Highlights: The Scheduled Tribes. https://censusindia.gov.in/Tables_Published/SCST/dh_st_manipur.pdf.

Ota, T. 1993. DISPAN: Genetic Distance and Phylogenetic Analysis. University Park, PA: Institute of Molecular Evolutionary Genetics, The Pennsylvania State University.

Panjaliya, R. K., V. Dogra, P. Kumar et al. 2012. Human-specific Alu insertion/deletion polymorphisms in various population groups of Jammu Region. Int. J. Hum. Genet. $12: 311-317$. 
Prabhakaran, K., A. Ramesh, U. Rani et al. 2008. Did human DRD2 haplotypes originate in India? A survey of haplotype frequencies and linkage disequilibrium in the tribes of Eastern Ghats, South India. Curr. Sci. 94:1,589-1,594.

Rizvi, S. H. M., and S. Roy 2006. Kuki-Chin Tribes of Mizoram and Manipur. New Delhi, IND: B.R. Publishing Corporation.

Saraswathy, K. N., N. Kiranmala, B. Murry et al. 2009a. A genomic insight into diversity among tribal and non-tribal population groups of Manipur, India. Biochem. Genet. 47:694-706.

Saraswathy, K. N., S. Y. Meitei, V. Gupta et al. 2010. Brief communication: Allelic and haplotypic structure at the DRD2 locus among five North Indian caste populations. Am. J. Phys. Anthropol. 141:651-657.

Saraswathy, K. N., R. Mukhopadhyay, D. Shukla et al. 2009c. Haplotype diversity and linkage disequilibrium at DRD2 locus - A study on four population groups of Andhra Pradesh, India. Genet. Test. Mol. Biomarkers 13:115-119.

Saraswathy, K. N., M. P. Sachdeva, R. Mukhopadhyay et al. 2008. Diversified genomic contribution among south Indian populations-A study on four endogamous groups of Andhra Pradesh. Ann. Hum. Biol. 35:499-508.

Saraswathy, K. N., Y. M. Sanjenbam, B. Murry et al. 2009b. Population severance in Manipur at dopamine receptor D2 locus. Genet. Test. Mol. Biomarkers 13:831-839.

Singh, O. K. 1983a. Archaeology in Manipur, Napachik: A Stone Age Site in the Manipur Valley. Manipur, IND: State Archaeology Department, Government of Manipur.

Singh, O. K. 1983b. Archaeology of Manipur. Manipur, IND: State Archaeology Department, Government of Manipur. 
Singh, O. K. 1997. Stone Age Archaeology of Manipur. Manipur, IND: Amusana Institute of Antiquarian Studies.

Sinha, M., P. K. Temunkar, P. Gajendra et al. 2015. Human dopamine receptor D2 (DRD2) polymorphisms among four tribal populations of Chhattisgarh, India. Asian Man Int. J. $9: 40-46$.

Stoneking, M., J. J. Frontius, S. L. Clifford et al. 1997. Alu insertion polymorphisms and human evolution: Evidence for a larger population size in Africa. Genome Res. 7:1,061-1,071.

Thurgood, G., and R. J. Lapolla, eds. 2003. The Sino-Tibetan Languages. New York: Routledge.

Tohring, S. R. 2010. Violence and Identity in North-East India: Naga-Kuki Conflict. New Delhi, IND: Mittal Publications.

Veerraju, P., T. V. Rao, N. Lakshmi et al. 2001. Insertion/deletion DNA polymorphisms in two south Indian tribal populations. Int. J. Hum. Genet. 1:129-132.

Vishwanathan, H., E. Deepa, R. Cordaux et al. 2004. Genetic structure and affinities among tribal populations of southern India: A study of 24 autosomal DNA markers. Ann. Hum. Genet. 68:128-138.

Vishwanathan, H., D. Edwin, M. V. Usharani et al. 2003. Insertion/deletion polymorphisms in tribal populations of southern India and their possible evolutionary implications. Hum. Biol. 75:873-887.

Xiao, F., J. Yang, J. Cassiman et al. 2002. Diversity at eight polymorphic Alu insertion loci in Chinese populations shows evidence for European admixture in an ethnic minority population from northwest China. Hum. Biol. 74:555-568.

Pre-print version. Visit http://digitalcommons.wayne.edu/humbiol/ after publication to acquire the final version. 
Yeh, F., and R. Yang. 1999. POPGENE: Microsoft Window-Based Freeware for Population Genetic Analysis, Version 1.31. Alberta, CA: University of Alberta and the Centre for International Forestry Research.

Pre-print version. Visit http://digitalcommons.wayne.edu/humbiol/ after publication to acquire the final version. 
Table 1. Allele Frequencies at 20 Autosomal Loci among the Study Tribal Populations of Manipur

\begin{tabular}{|c|c|c|c|c|c|c|c|c|c|c|c|c|}
\hline \multirow[t]{2}{*}{ Loci } & \multicolumn{3}{|c|}{ Rongmei } & \multicolumn{3}{|c|}{ Inpui } & \multicolumn{3}{|c|}{ Thadou } & \multicolumn{3}{|c|}{ Vaiphei } \\
\hline & $\mathbf{P}^{\mathbf{a}}$ & $\begin{array}{c}\text { Chi- } \\
\text { square }\end{array}$ & $2 n^{b}$ & $\overline{\mathbf{P}^{\mathbf{a}}}$ & $\begin{array}{c}\text { Chi- } \\
\text { square }\end{array}$ & $2 n^{b}$ & $\overline{\mathbf{P}^{\mathbf{a}}}$ & $\begin{array}{c}\text { Chi- } \\
\text { square }\end{array}$ & $2 n^{b}$ & $\mathbf{P}^{\mathbf{a}}$ & $\begin{array}{c}\text { Chi- } \\
\text { square }\end{array}$ & $2 n^{k}$ \\
\hline ACE & 0.509 & 1.302 & 202 & 0.505 & 1.101 & 200 & 0.608 & 2.633 & 130 & 0.652 & 0.726 & 66 \\
\hline APO & 0.728 & 0.582 & 180 & 0.810 & 0.444 & 174 & 0.900 & 0.314 & 130 & 0.818 & 1.388 & 66 \\
\hline PV92 & 0.744 & 0.246 & 160 & 0.695 & 2.369 & 174 & 0.719 & $19.093 *$ & 128 & 0.818 & $5.638^{*}$ & 66 \\
\hline FXIIIB & 0.573 & $12.017^{*}$ & 68 & 0.598 & $36.173^{*}$ & 122 & 0.425 & $57.005^{*}$ & 120 & 0.517 & $22.438^{*}$ & 58 \\
\hline mt-NUC & 0.467 & 2.089 & 122 & 0.500 & 0.003 & 170 & 0.333 & 0.399 & 126 & 0.409 & 0.083 & 66 \\
\hline D1 & 0.279 & 1.252 & 186 & 0.216 & 0.473 & 134 & 0.283 & 2.129 & 120 & 0.109 & 1.632 & 64 \\
\hline CD4 & 0.956 & $35.172 *$ & 138 & 0.982 & $115.008^{*}$ & 116 & 0.926 & $7.814^{*}$ & 54 & 0.891 & 3.286 & 46 \\
\hline PLAT & 0.555 & 0.218 & 182 & 0.511 & 1.992 & 182 & 0.405 & 0.175 & 126 & 0.364 & 0.323 & 66 \\
\hline ESR & 0.627 & 3.671 & 142 & 0.531 & 0.354 & 196 & 0.745 & 1.456 & 106 & 0.808 & 1.307 & 52 \\
\hline NAT & 0.91 & 1.319 & 100 & 0.904 & 0.372 & 136 & 0.867 & 0.001 & 120 & 0.726 & 0.492 & 62 \\
\hline PSCR & 0.057 & 0.254 & 158 & 0.033 & 0.086 & 184 & 0.25 & 0.409 & 132 & 0.151 & 0.935 & 66 \\
\hline $\mathbf{T} 2$ & 0.359 & 0.909 & 156 & 0.372 & 1.857 & 188 & 0.492 & 0.891 & 126 & 0.379 & 0.208 & 66 \\
\hline LPL & 0.679 & 0.418 & 184 & 0.676 & 1.068 & 176 & 0.395 & 0.054 & 124 & 0.406 & 0.381 & 64 \\
\hline HOXB4 & 0.556 & 0.008 & 124 & 0.48 & 0.177 & 148 & 0.623 & 0.001 & 114 & 0.621 & 0.693 & 58 \\
\hline Hb 7 & 0.404 & 0.062 & 136 & 0.477 & 1.747 & 130 & 0.207 & 0.235 & 116 & 0.227 & $5.743^{*}$ & 66 \\
\hline Hb 8 & 0.312 & 0.365 & 138 & 0.316 & 0.000 & 152 & 0.173 & 0.17 & 110 & 0.076 & $5.289^{*}$ & 66 \\
\hline Hb 9 & 0.825 & 0.172 & 166 & 0.857 & 0.423 & 168 & 0.811 & 0.541 & 106 & 0.734 & 0.592 & 64 \\
\hline Taq I B & 0.618 & 1.253 & 136 & 0.649 & 2.824 & 154 & 0.446 & 1.128 & 112 & 0.531 & 2.213 & 64 \\
\hline Taq I D & 0.779 & 0.754 & 136 & 0.809 & 1.601 & 152 & 0.275 & 0.134 & 120 & 0.259 & 0.024 & 58 \\
\hline Taq I A & 0.507 & 2.686 & 136 & 0.622 & 0.001 & 156 & 0.186 & 2.012 & 134 & 0.288 & 1.945 & 66 \\
\hline
\end{tabular}

${ }^{\text {a }}$ frequency of ' + ' allele; ${ }^{\mathbf{b}}$ number of chromosome tested; * significant at $\mathrm{p} \leq 0.05$ 
Table 2. Heterozygosity at Individual Loci and Average Heterozygosity Based on 20 Autosomal DNA Loci among the Study Tribal Populations of Manipur

\begin{tabular}{|c|c|c|c|c|}
\hline Loci & Rongmei & Inpui & Thadou & Vaiphei \\
\hline $\mathrm{ACE}$ & 0.499 & 0.499 & 0.477 & 0.454 \\
\hline APO & 0.396 & 0.307 & 0.180 & 0.298 \\
\hline PV92 & 0.381 & 0.424 & 0.404 & 0.298 \\
\hline FXIIIB & 0.489 & 0.481 & 0.489 & 0.499 \\
\hline mt-NUC & 0.498 & 0.500 & 0.444 & 0.483 \\
\hline D1 & 0.403 & 0.339 & 0.406 & 0.194 \\
\hline CD4 & 0.832 & 0.338 & 0.137 & 0.194 \\
\hline PLAT & 0.494 & 0.499 & 0.482 & 0.463 \\
\hline ESR & 0.468 & 0.498 & 0.379 & 0.310 \\
\hline NAT & 0.164 & 0.173 & 0.231 & 0.398 \\
\hline PSCR & 0.107 & 0.638 & 0.375 & 0.258 \\
\hline $\mathrm{T} 2$ & 0.460 & 0.467 & 0.499 & 0.471 \\
\hline LPL & 0.436 & 0.438 & 0.478 & 0.482 \\
\hline HOXB4 & 0.493 & 0.499 & 0.469 & 0.471 \\
\hline $\mathrm{Hb} 7$ & 0.482 & 0.499 & 0.328 & 0.351 \\
\hline $\mathrm{Hb} 8$ & 0.429 & 0.432 & 0.286 & 0.140 \\
\hline $\mathrm{Hb} 9$ & 0.288 & 0.245 & 0.307 & 0.390 \\
\hline Taq I B & 0.472 & 0.455 & 0.494 & 0.498 \\
\hline Taq I D & 0.344 & 0.309 & 0.399 & 0.384 \\
\hline Taq I A & 0.499 & 0.470 & 0.304 & 0.410 \\
\hline All loci & 0.394 & 0.382 & 0.378 & 0.372 \\
\hline
\end{tabular}


Table 3. Gene Diversity Estimates Based on 20 Autosomal DNA Loci among the Study Tribal Populations of Manipur

\begin{tabular}{llll}
\hline Loci & $\mathrm{H}_{\mathrm{T}}$ & $\mathrm{H}$ & GsT \\
\hline ACE & 0.490 & 0.482 & 0.016 \\
APO & 0.303 & 0.295 & 0.024 \\
PV92 & 0.381 & 0.377 & 0.011 \\
FXIIIB & 0.498 & 0.489 & 0.018 \\
mt-NUC & 0.489 & 0.481 & 0.016 \\
D1 & 0.345 & 0.335 & 0.029 \\
CD4 & 0.114 & 0.112 & 0.020 \\
PLAT & 0.496 & 0.485 & 0.024 \\
ESR & 0.437 & 0.414 & 0.052 \\
NAT & 0.252 & 0.241 & 0.044 \\
PSCR & 0.216 & 0.201 & 0.068 \\
T2 & 0.480 & 0.474 & 0.012 \\
LPL & 0.497 & 0.459 & 0.077 \\
HOXB4 & 0.490 & 0.483 & 0.014 \\
Hb 7 & 0.441 & 0.415 & 0.059 \\
Hb 8 & 0.342 & 0.322 & 0.059 \\
Hb 9 & 0.312 & 0.308 & 0.013 \\
Taq I B & 0.492 & 0.479 & 0.025 \\
Taq I D & 0.498 & 0.358 & 0.279 \\
Taq I A & 0.480 & 0.421 & 0.123 \\
Average & 0.403 & 0.382 & 0.052 \\
\hline
\end{tabular}

$\mathrm{H}_{\mathrm{T}}$ Total average heterozygosity, $\mathrm{H}_{\mathrm{s}}$ individual variation within population, Gst degree of genetic variation 
Table 4. Haplotype Frequency Distribution at Three Sites TaqI 'B', TaqI 'D' and TaqI 'A' at the DRD2 System among the Study Populations of Manipur

\begin{tabular}{lllll}
\hline DRD2 haplotypes & \multicolumn{3}{c}{ Population groups } \\
\cline { 2 - 5 } & Rongmei & Inpui & Thadou & Vaiphei \\
\hline B2D2A2 & 0.356 & 0.444 & 0.319 & 0.266 \\
B2D1A2 & 0.047 & 0.074 & 0.115 & 0.153 \\
B1D2A2 & 0.053 & 0.101 & 0.261 & 0.249 \\
B1D1A2 & 0.044 & 0.000 & 0.089 & 0.028 \\
B2D2A1 & 0.156 & 0.112 & 0.087 & 0.081 \\
B2D1A1 & 0.059 & 0.023 & 0.048 & 0.000 \\
B1D2A1 & 0.214 & 0.170 & 0.000 & 0.136 \\
B1D1A1 & 0.071 & 0.076 & 0.081 & 0.087 \\
\hline
\end{tabular}

B2,D2,A2: Alleles for presence of restriction sites at $\operatorname{TaqI}$ 'B', TaqI 'D', TaqI 'A' respectively

Values in bold: Ancestral haplotype frequencies 
Table 5. Haplotype Frequency Distribution at Three Sites Hb9, $\mathrm{Hb8}$ and $\mathrm{Hb} 7$ at the $\beta$-globin System among the Study Populations of Manipur

\begin{tabular}{lllll}
\hline Haplotype frequencies & \multicolumn{3}{c}{ Population groups } \\
\cline { 2 - 5 } & Rongmei & Inpui & Thadou & Vaiphei \\
\hline$(+++)$ & 0.172 & 0.154 & 0.073 & 0.062 \\
$(++-)$ & 0.149 & 0.191 & 0.078 & 0.000 \\
$(+--)$ & 0.345 & 0.315 & 0.574 & 0.602 \\
$(-++)$ & 0.000 & 0.039 & 0.016 & 0.016 \\
$(---)$ & 0.046 & 0.044 & 0.119 & 0.164 \\
$(++)$ & 0.054 & 0.222 & 0.056 & 0.086 \\
$(-+-)$ & 0.193 & 0.018 & 0.031 & 0.000 \\
$(--+)$ & 0.041 & 0.017 & 0.053 & 0.070 \\
\hline
\end{tabular}

${ }^{\mathrm{a}}+$ Presence of restriction site - Absence of restriction site 
Table 6. Extent of Genetic Differentiation Estimated by AMOVA among Presently Studied Populations, Other Indian and Southeast Asian Populations on the Basis of Autosomal Markers

\begin{tabular}{|c|c|c|c|}
\hline Category $^{\mathrm{a}}$ & $\begin{array}{c}\text { Among groups } \\
\text { variance }(\operatorname{In} \%)^{\mathrm{C}}\end{array}$ & $\begin{array}{l}\text { Among Populations within } \\
\text { groups variance }(\operatorname{In} \%)^{\mathrm{C}}\end{array}$ & $\begin{array}{l}\text { Within Population } \\
\text { variance }(\text { In } \%)^{\mathrm{C}}\end{array}$ \\
\hline $\begin{array}{l}\text { 1. Nagas and Kukis of the present } \\
\text { study }(20)^{\mathrm{b}}\end{array}$ & 7.09 & 0.31 & 92.60 \\
\hline 2. PS and Southeast Asia (5) & 1.18 & 1.83 & 96.99 \\
\hline $\begin{array}{l}\text { 3. Castes and Tribal groups of India } \\
(11)^{\mathrm{b}}\end{array}$ & 1.92 & 4.91 & 93.17 \\
\hline $\begin{array}{l}\text { 4. Four Linguistic groups of India } \\
(11)^{\mathrm{b}}\end{array}$ & 3.23 & 2.64 & 94.13 \\
\hline
\end{tabular}

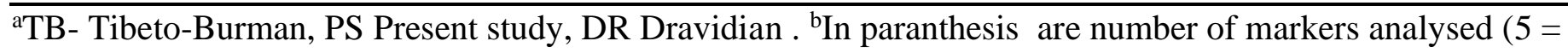
ACE, APO, D1, PLAT and PV92; 11 = ACE, APO, D1, PLAT, PV92, CD4, ESR, NAT, PSCR, T2, LPL; $20=$ ACE, APO, D1, PLAT, PV92, mt-NUC, CD4, FXIIIB, ESR, NAT, PSCR, T2, LPL, HOXB4, Hb 7, Hb 8, Hb 9, TaqI B, TaqI D, TaqI A) ${ }^{\mathrm{C}}$ The values are significant, $\mathrm{p}<0.05$ 
Supplementary Table S1. Genotype Distribution at FXIIIB, CD4, PV92, Hb7 and Hb8 Loci which Are

Getting Significant Values in the Present Study

\begin{tabular}{|c|c|c|c|c|c|c|c|c|c|}
\hline \multirow[t]{2}{*}{ Loci } & \multirow[t]{2}{*}{ Genotype } & \multicolumn{4}{|c|}{ Observed } & \multicolumn{4}{|c|}{ Expected } \\
\hline & & Thadou & Vaiphei & Inpui & Rongmei & Thadou & Vaiphei & Inpui & Rongmei \\
\hline \multirow[t]{3}{*}{ FXIIIB } & ++ & 25 & 14 & 33 & 16 & 10.71 & 7.63 & 21.72 & 11.06 \\
\hline & +- & 1 & 2 & 7 & 7 & 29.57 & 14.74 & 29.56 & 16.88 \\
\hline & - & 34 & 13 & 21 & 11 & 19.71 & 6.63 & 9.72 & 6.06 \\
\hline \multirow[t]{3}{*}{ CD4 } & ++ & 24 & & 57 & 65 & 23.11 & & 56.01 & 63.11 \\
\hline & +- & 2 & & 0 & 2 & 3.77 & & 1.98 & 5.78 \\
\hline & -- & 1 & & 1 & 2 & 0.11 & & 0.008 & 0.11 \\
\hline \multirow[t]{3}{*}{ PV92 } & ++ & 40 & 24 & & & 32.96 & 22.01 & & \\
\hline & +- & 12 & 6 & & & 26.08 & 9.97 & & \\
\hline & -- & 12 & 3 & & & 4.96 & 1.02 & & \\
\hline \multirow[t]{3}{*}{$\mathrm{Hb}-7$} & ++ & & 4 & & & & 1.62 & & \\
\hline & +- & & 7 & & & & 11.77 & & \\
\hline & -- & & 22 & & & & 19.61 & & \\
\hline \multirow[t]{3}{*}{$\mathrm{Hb}-8$} & ++ & & 1 & & & & 0.15 & & \\
\hline & +- & & 3 & & & & 4.69 & & \\
\hline & -- & & 29 & & & & 28.15 & & \\
\hline
\end{tabular}

++ Homozygous for presence of restriction

+- Heterozygous for presence and absence of restriction site

-- Restriction site absent

Pre-print version. Visit http://digitalcommons.wayne.edu/humbiol/ after publication to acquire the final version. 
Supplementary Table S2. Allele Frequencies at Alu InDel Loci among the Populations of Manipur ${ }^{1}$

Considered for Gst Analysis

\begin{tabular}{|l|c|c|c|c|c|c|c|c|c|c|}
\hline \multirow{2}{*}{} & \multicolumn{2}{|c|}{ ACE } & \multicolumn{2}{c|}{ APO } & \multicolumn{2}{c|}{ PV92 } & \multicolumn{2}{c|}{ PLAT } & \multicolumn{2}{c|}{ D1 } \\
\cline { 2 - 10 } & $+^{2}$ & $\mathbf{s}^{3}$ & + & - & + & - & + & - & + & - \\
\hline Thadou & 0.608 & 0.392 & 0.900 & 0.100 & 0.719 & 0.281 & 0.405 & 0.595 & 0.283 & 0.717 \\
\hline Vaiphei & 0.652 & 0.348 & 0.818 & 0.182 & 0.818 & 0.182 & 0.364 & 0.636 & 0.109 & 0.891 \\
\hline Rongmei & 0.509 & 0.491 & 0.728 & 0.272 & 0.744 & 0.256 & 0.555 & 0.445 & 0.279 & 0.721 \\
\hline Inpui & 0.505 & 0.495 & 0.81 & 0.190 & 0.695 & 0.305 & 0.511 & 0.489 & 0.216 & 0.784 \\
\hline Zeme & 0.471 & 0.529 & 0.829 & 0.171 & 0.835 & 0.165 & 0.378 & 0.622 & 0.217 & 0.783 \\
\hline Liangmai & 0.451 & 0.549 & 0.775 & 0.225 & 0.868 & 0.132 & 0.356 & 0.644 & 0.220 & 0.780 \\
\hline Meitei & 0.544 & 0.456 & 0.917 & 0.083 & 0.676 & 0.324 & 0.452 & 0.548 & 0.263 & 0.737 \\
\hline Paite & 0.675 & 0.325 & 0.905 & 0.095 & 0.779 & 0.221 & 0.440 & 0.560 & 0.315 & 0.685 \\
\hline Kom & 0.259 & 0.741 & 0.906 & 0.094 & 0.437 & 0.563 & 0.448 & 0.552 & 0.454 & 0.546 \\
\hline Aimol & 0.587 & 0.413 & 0.923 & 0.077 & 0.882 & 0.118 & 0.431 & 0.569 & 0.350 & 0.650 \\
\hline Manipur Bamon & 0.591 & 0.409 & 0.722 & 0.278 & 0.633 & 0.367 & 0.419 & 0.581 & 0.351 & 0.649 \\
\hline Manipur Muslim & 0.573 & 0.427 & 0.824 & 0.176 & 0.440 & 0.560 & 0.598 & 0.402 & 0.280 & 0.720 \\
\hline
\end{tabular}

${ }^{1}$ Reference for secondary source data: Saraswathy et al. (2009a); Meitei et al. (2010); Kshatriya et al. (2019)

${ }^{2}$ Frequency of insertion allele ${ }^{3}$ Frequency of deletion allele

Pre-print version. Visit http://digitalcommons.wayne.edu/humbiol/ after publication to acquire the final version. 


\section{Supplementary Document S1. Certificate of Ethical Clearance}

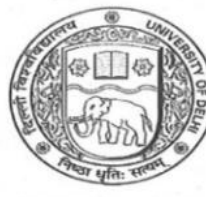

DEPARTMENT OF ANTHROPOLOGY

UNIVERSITY OF DELHI

DELHI- 110007

ETHICAL COMMITTEE

CHAIRMAN \& MEDICAL DOCTOR
Dr. M. M. Singh
Department of Community
Medicine HAH
Maulana Azad Medical College,
Delhi
LAWYER
Prof. A. K. Bansal, Ph.D.
Faculty of Law, Uni. of Delhi,
Delhi 110007.
PHILOSOPHER
Dr. H.P. Gangnegi, Ph.D.
Department of Buddhist Studies
University of Delhi
Delhi - 110007
BIOLOGY SCIENTIST
Dr. A. K. Kapoor, Ph.D.
Professor
Department of Anthropology
University of Delhi
Delhi- 110007
SOCIAL SCIENTISTS
Prof. Anita Sharma, Ph.D.
Dean, Faculty of Social Science
University of Delhi
Delhi - 110007
Dr. P. C. Joshi, Ph.D.
Professor
Department of Anthropology
University of Delhi
Professor,
Department of Anthi- 110007
University of Delhi
Delhi- 110007
COMMology
Mr. Raj Mohan
C-143, Reid's Line, North Delhi
Delhi- 110007

Ref. No./2015/

22 May 2015

The ethical Committee of the Department of Anthropology met on 30 April 2015 at 3:30 p.m. in Department of Anthropology to consider the research project titled, "A Study of Genomic diversity among the selected tribes of Manipur" of Prof. G. K. Kshatriya, Principal Investigator.

The Investigator on being asked informed the committee that in depth interviews and detailed case-studies would be taken. The data on variables like personal identification and anthropometric measurements along with blood samples would be collected after obtaining informed written consent from each subject. It was further informed that the used needles would be disposed off as per the guidelines of Bio-Medical Waste Management Act.

The Research project is approved by the Ethical Committee and ethical clearance is given to the above mentioned research project after ensuring the safety and confidentiality of the data collected and also the safety of the subject while collecting the data.

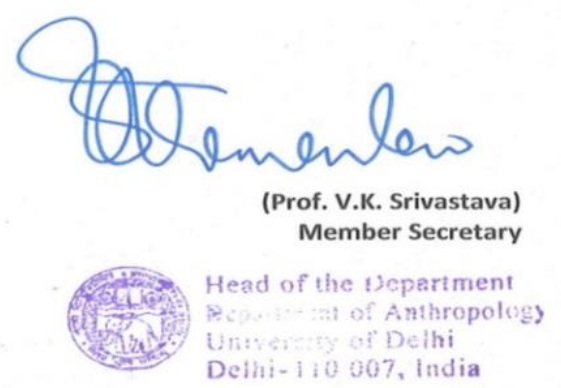

Pre-print version. Visit http://digitalcommons.wayne.edu/humbiol/ after publication to acquire the final version. 


\section{Figure Captions}

Figure 1. Position of Manipur in the map of India (top); Regions of sample collections highlighted in the map of Manipur (bottom).

Figure 2. Distribution of allele frequency among the four presently studied populations on the basis of 20 markers

Figure 3. Distribution of Alu allele frequencies among Indian and the world populations. Sources: Mukherjee et al. 2000; Vishwanathan et al. 2003; Xiao et al. 2002; Meitei et al. 2010; Kshatriya et al. 2011; Panjaliya et al. 2012; Kshatriya et al. 2019; ALFRED database.

Figure 4. Multidimensional scaling (MDS) plot depicting the genetic relationships between the Kuki tribal groups, Southeast Asian and European on the basis of five AluInDel markers (PV92, D1, APO, ACE and PLAT)

Figure 5. Multidimensional scaling (MDS) plot depicting the genetic relationships of 44 global populations (present study populations, other Indian populations and other world populations) on the basis of five AluInDel markers (PV92, D1, APO, ACE and PLAT) 
Figure 1.

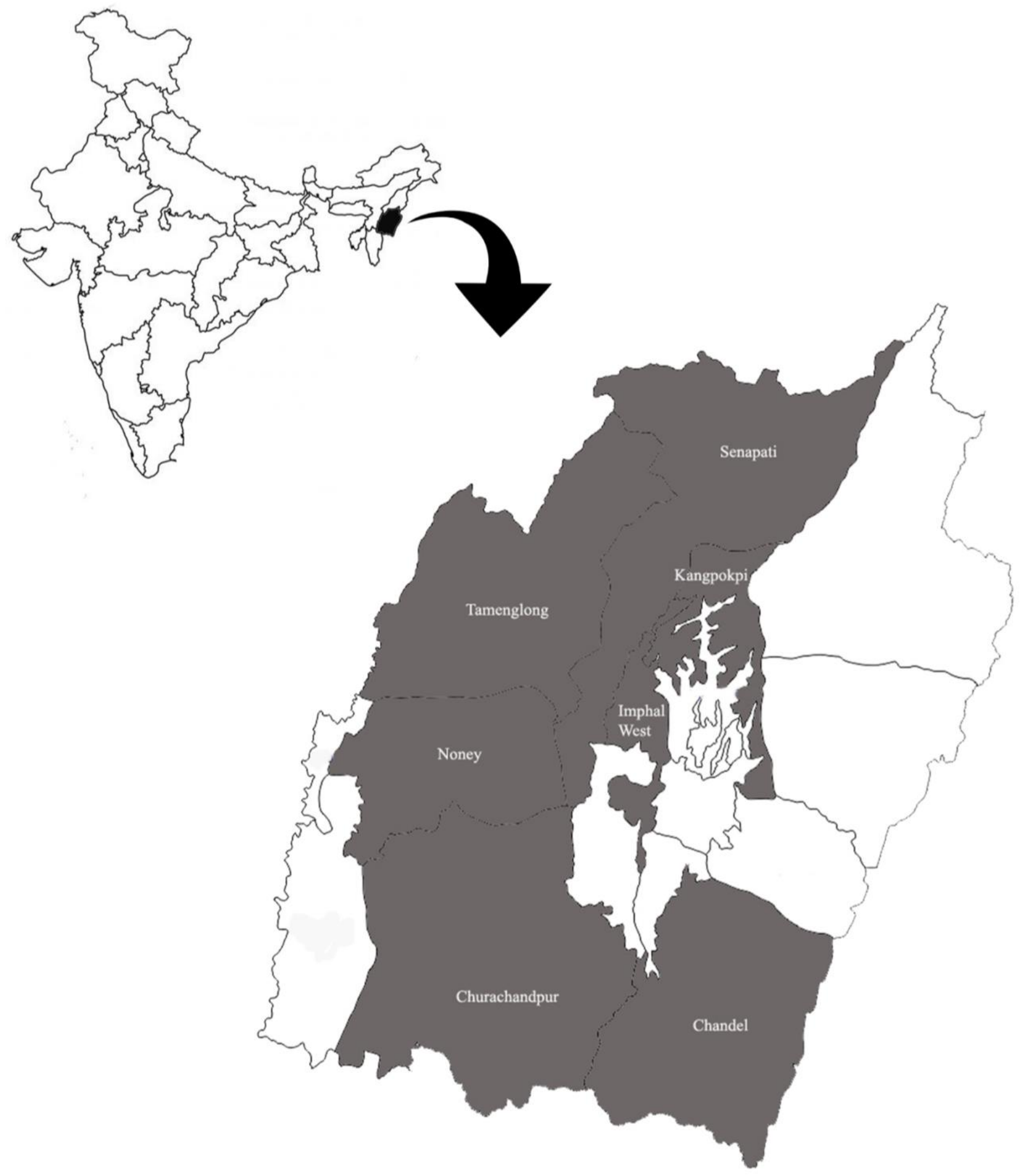

Pre-print version. Visit http://digitalcommons.wayne.edu/humbiol/ after publication to acquire the final version. 
Figure 2.

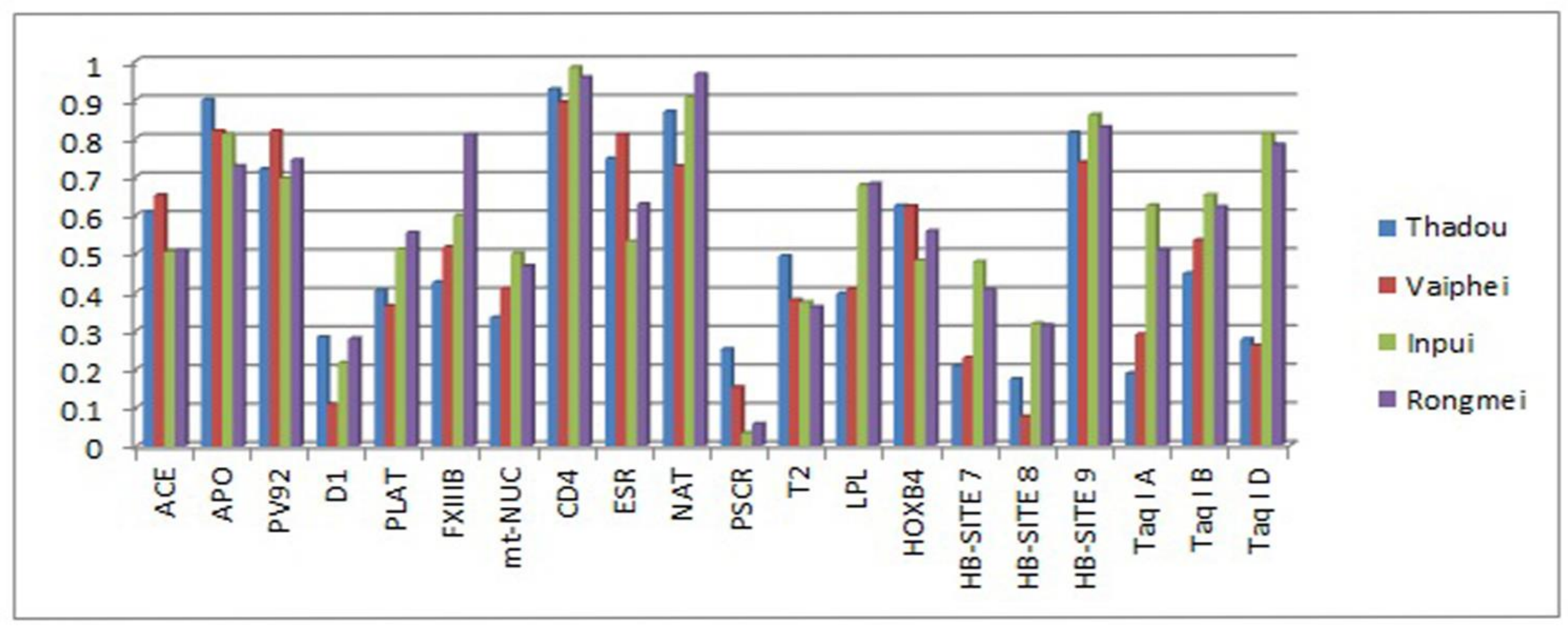


Figure 3.

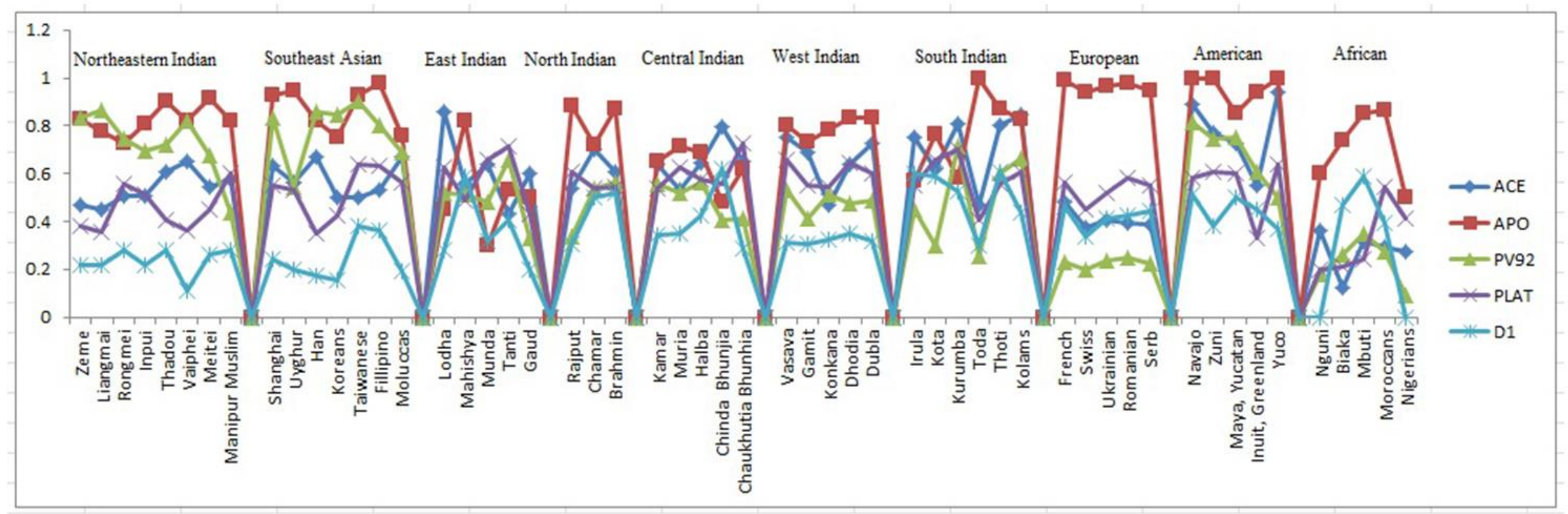


Figure 4.

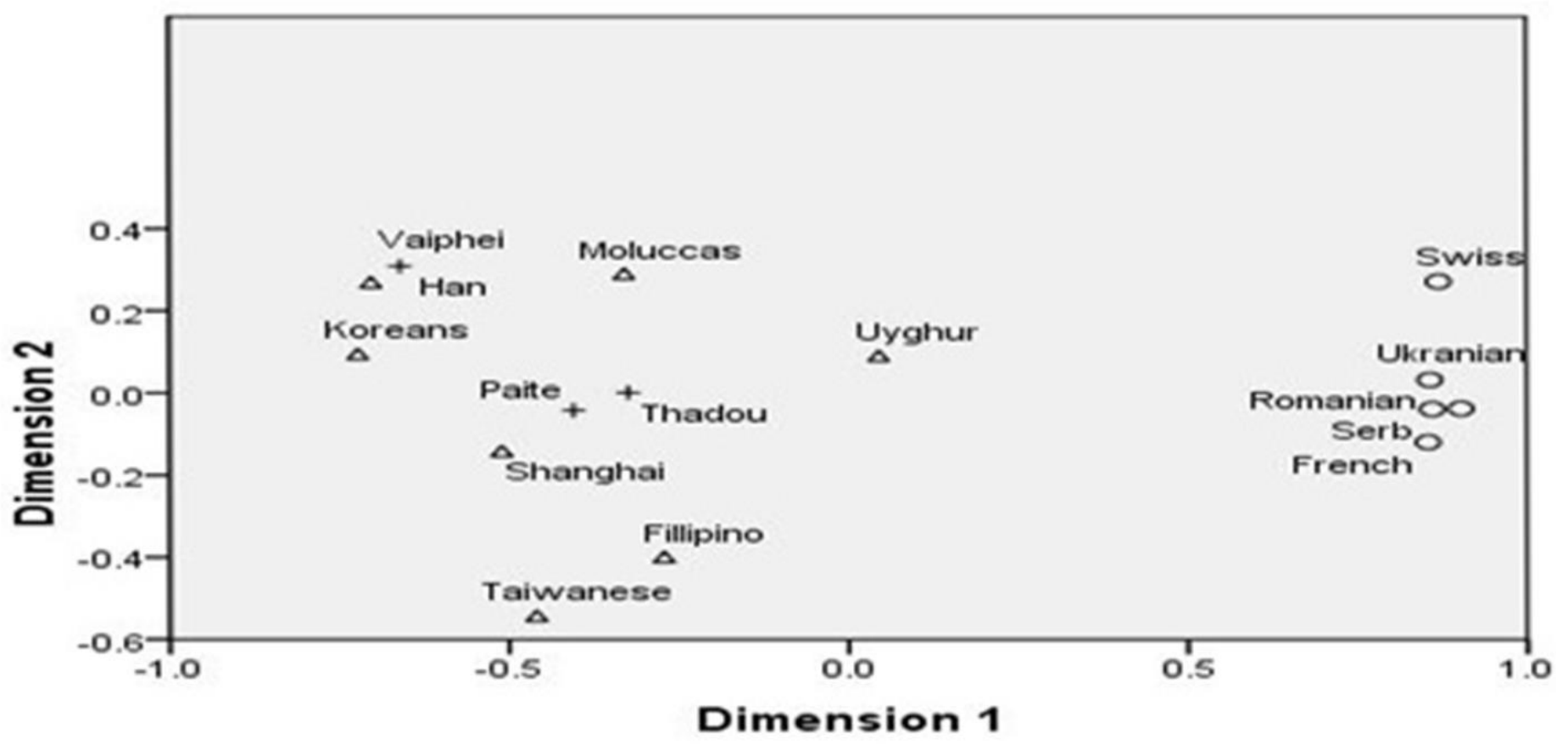

+ Kuki tribal groups $\Delta$ Southeast Asian $\circ$ European 
Figure 5.

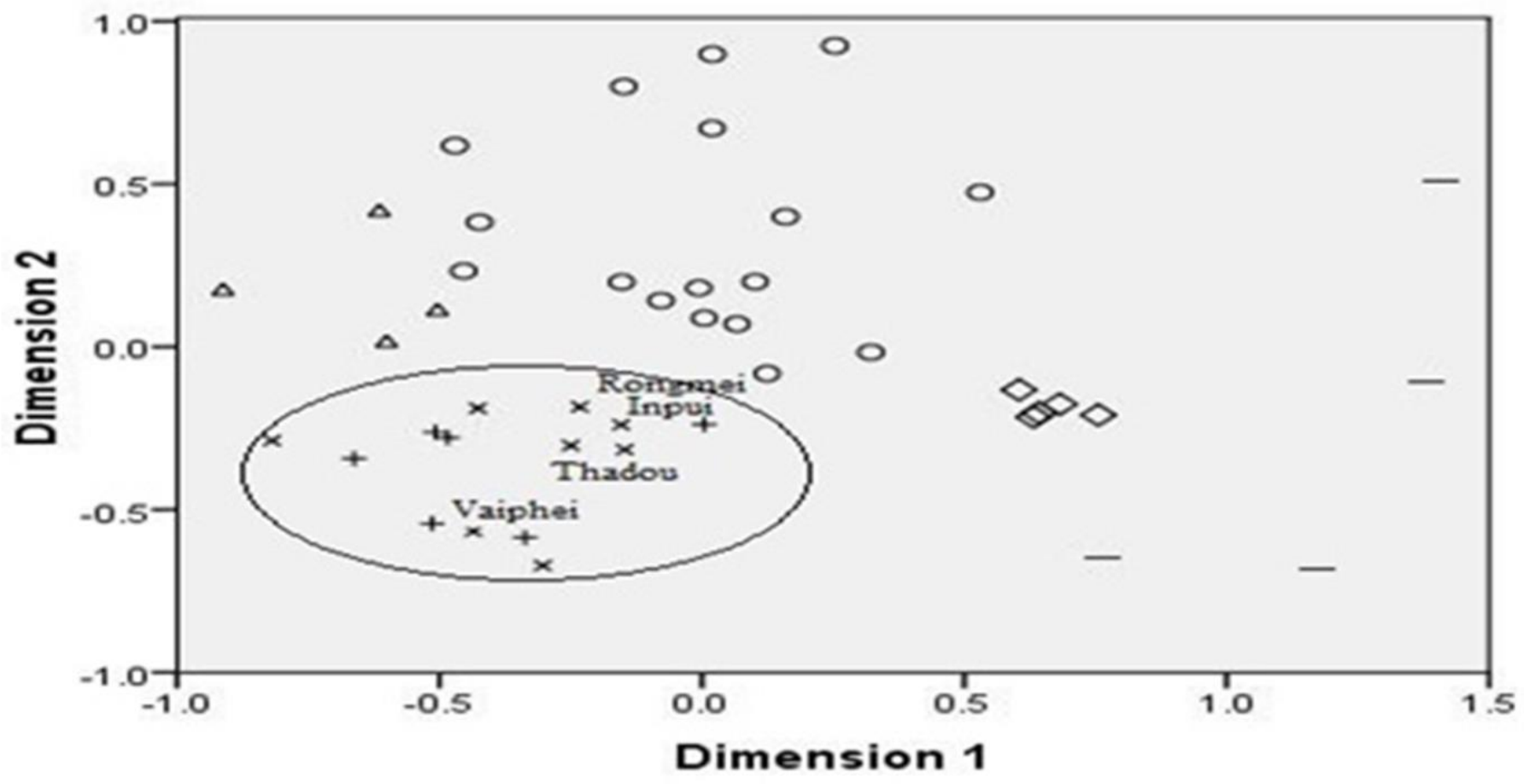

+ Southeast Asian $\circ$ other Indian - African

$\checkmark$ European $\Delta$ American $\mathrm{x}$ Northeast Indian 